\section{NOVA TELLVS}

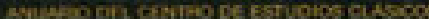

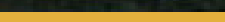

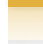
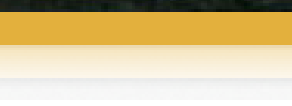

Nova Tellus

ISSN: 0185-3058

novatelu@servidor.unam.mx

Centro de Estudios Clásicos

México

Gálvez Garduño, Rafael

La poesía de Parménides: el arte del estilo ambiguo y desafiante, insinuador y sutil

Nova Tellus, vol. 26, núm. 1, 2008, pp. 55-90

Centro de Estudios Clásicos

Distrito Federal, México

Disponible en: http://www.redalyc.org/articulo.oa?id=59115488002

- Cómo citar el artículo

- Número completo

- Más información del artículo

Página de la revista en redalyc.org

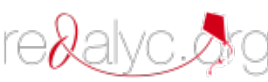

Sistema de Información Científica

Red de Revistas Científicas de América Latina, el Caribe, España y Portugal Proyecto académico sin fines de lucro, desarrollado bajo la iniciativa de acceso abierto 


\title{
La poesía de Parménides: el arte del estilo ambiguo y desafiante, insinuador y sutil
}

\author{
Rafael GÁlVEZ GARDUÑO \\ Universidad Nacional Autónoma de México \\ ragalgar@gmail.com
}

\begin{abstract}
RESUMEN: En este trabajo se realiza un análisis del proemio del poema de Parménides con la intención de mostrar cómo su construcción está sabiamente acabada tanto en el plano literario de la factura artística, como en el del proyecto comunicativo, que plantea un reto a la inteligencia del auditorio. Éste, en efecto, se ve sometido a un haz de estímulos a menudo contradictorios, que van de la ambigüedad expresiva a la insinuación sutil, cuyos efectos están destinados por cierto a tocar cuerdas muy sensibles en el receptor. Sentadas estas premisas, se sugiere que el contraste entre el fascinante relato alegórico del proemio y la parte propiamente filosófica del poema de Parménides puede depender de su gestación en dos diferentes etapas de la vida del filósofo, en la primera de las cuales la influencia de la epopeya homérica resulta insoslayable.
\end{abstract}

$$
* * *
$$

ABSTRACT: This paper analyzes the proem of Parmenides' poem to the scope of showing how it is skillfully constructed both at the level of the artistic finish and as regards the communicative frame, which is designed to pose a challenge to the intelligence of the hearer. Actually, the receiver is exposed to a bundle of stimuli quite often contradictory, ranging from expressive ambiguity to subtle insinuation, with effects that are indeed devised to strike very sensitive chords in his/her mind. On these assumptions, it is then argued that the contrast between the fascinating story narrated in the allegorical proem and the really philosophical section of Parmenides' poem may depend on their gestation at two different stages in this philosopher's life. It is on the first of them that the influence of the Homeric epos is inescapable.

PAlabRas ClaVE: estilo poético, Homero, Parménides, sabiduría.

RECEPCIÓN: 28 de enero de 2008.

ACEPTACIÓN: 11 de abril de 2008. 


\title{
La poesía de Parménides: \\ el arte del estilo ambiguo y desafiante, insinuador y sutil
}

\author{
Rafael GÁlVEZ GARDUÑO
}

\begin{abstract}
A la memoria de Paola Vianello
Quien quiera enseñarnos alguna verdad, que no nos la diga; simplemente que aluda a ella con un breve gesto... que nos sitúe de modo que la descubramos nosotros.

J. Ortega y Gasset, Meditaciones del Quijote
\end{abstract}

A juzgar por la afortunada conservación de importantes fragmentos del Poema de Parménides, gracias sobre todo a Sexto Empírico, Simplicio y Proclo, que nos transmitieron un gran porcentaje, probablemente más del $95 \%$ de lo que era el poema original, al menos hasta el Fr. 8 inclusive, era de esperarse que poseyéramos ya, con suficiente precisión y extensión, el pensamiento de nuestro filósofo. Sin embargo, el estado actual que muestra la labor de los estudiosos en la interpretación del texto deja mucho que desear, pues desconcierta el hecho de no haber un acuerdo entre ellos acerca de varios aspectos del pensamiento que intentan desentrañar. Y esto debido sin duda a las dificultades que presenta el modo de expresión de Parménides, que, a mi parecer, fue determinado y decidido por su autor de una manera cuidadosamente estudiada. Por ello me parece que decir que éste "No tiene facilidad de dicción"1 es juzgar superficialmente y no captar el fondo y el carácter de su estilo. El mismo autor citado observa enseguida: "y su esfuerzo por

\footnotetext{
${ }^{1}$ G. S. Kirk, J. E. Raven, y M. Schofield, Los Filósofos Presocráticos, Madrid, Gredos, 1983 (2a. ed.), p. 349.
} 
construir sus nuevas ideas, difíciles y sumamente abstractas, ${ }^{2}$ a una forma métrica, desemboca en una oscuridad constante, especialmente en su sintaxis". Y esta oscuridad del texto, parece suponer M. Schofield, es la consecuencia inevitable de aquel esfuerzo fallido. Más perspicaz me parece, en cambio, la observación de D. Gallop: "Su sintaxis está repleta de ambigüedades, que son con frecuencia tan burlonas como para argumentar un oscurantismo deliberado o al menos una cierta perversidad por parte de su autor". ${ }^{3}$ Esto al menos supone en Parménides un propósito deliberado, aunque más bien siniestro.

Pero un gran estudioso de la poesía griega, C. M. Bowra, nos sorprende con un juicio de índole totalmente distinta:

Parménides era un escritor cuidadoso y singularmente exacto, y la composición de su Proemio sin duda le costó tanto trabajo como la exposición de la realidad que le sigue. En él tenía algo muy importante que decir, y adoptó un método notable con el cual la poesía griega difícilmente presenta algún paralelo. ${ }^{4}$

En nuestro estudio, partimos del juicio de Bowra, pues, al menos, nos predispone a intentar aguzar nuestras capacidades mentales para no quedar muy por debajo de las de nuestro filósofo.

Cuando nos enfrentamos al Poema de Parménides después de enterarnos grosso modo de su contenido, puede ser que nos llame la atención el contraste que nos presenta su autor entre sus dos partes constitutivas. En efecto, salta a la vista que el Poema consta de dos partes con características distintivas: comienza con un pintoresco relato fantástico, que termina pro-

\footnotetext{
${ }^{2}$ Es un lugar común la observación de lo difícil y abstracto del pensamiento de Parménides. Pero me parece que esta impresión está influída por las dificultades de su estilo.

${ }^{3}$ D. Gallop, Parmenides of Elea: Fragments, Toronto, University of Toronto Press, 1984, p. 4.

${ }^{4}$ C. M. Bowra, "The Proem of Parménides", Classical Philology, 32, 1937, p. 97. La cursiva es mía.
} 
piamente en B1. 28 a, al que sigue un discurso filosófico de aspecto e índole muy diferentes. ${ }^{5}$

¿Qué relación puede haber entre estas dos partes? ¿Qué pudo haber llevado a Parménides a colocar un relato figurativo como introducción a un discurso filosófico de carácter más bien abstracto? Una vez iniciado (B1. 28 b), de una manera ciertamente abrupta, este discurso, no vuelven a mencionarse los elementos figurativos de la primera parte, con excepción de ciertas vías

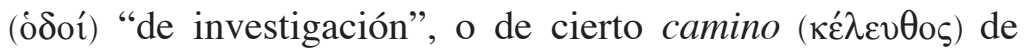
persuasión (el concepto de persuasión aparece también en el Proemio: B1. 16, pero en circunstancias muy diferentes, pues parece que ahí se trata de persuadir engañando: $\pi \alpha \rho \varphi \alpha ́ \mu \varepsilon v \alpha 1$, v. 15), o de cierto sendero ( $\dot{\alpha} \tau \alpha \rho \pi$ óv) inescrutable, que recuerdan las vías o caminos del Proemio. Pero acá son "caminos del pensamiento", son vías o caminos en sentido simbólico. Esto puede tomarse como una invitación a entender las vías y caminos del Proemio en el mismo sentido, lo que llevaría a extender a los demás elementos narrativos de aquella primera parte del Poema una significación de la misma naturaleza. Con esto estaríamos confiriendo al Proemio un sentido alegórico que, más que el meramente literal, concordaría mejor con su papel de introducción al discurso que le sigue. Tal vez de esta manera podríamos descubrir en él alguna oblicuidad que nos lleve, por ejemplo, a entender el relato como el itinerario que siguió Parménides en su búsqueda de la Verdad. Sin embargo, hay momentos del relato que muestran una franca literalidad, como la intervención de las Helíades para persuadir a Díke a que abra las puertas, o las palabras de bienvenida que dirige la diosa al "joven" (otro elemento que parece deber entenderse literalmente) que relata su experiencia. De acuerdo con esto, el Proemio pudiera tener dos lecturas, una literal y la otra alegórica. Los estudiosos de Parménides tienden a inclinarse, en

5 J. Mansfeld, Die Offenbarung des Parmenides und die menschliche Welt, Assen, Van Gorcum, 1964, p. 222. 
su interpretación, por una lectura o por la otra, no por ambas. Pero no habría mayor conflicto en ello, pues los pasajes con franca literalidad podrían tener mayor peso en la lectura literal y menor en la alegórica.

La lectura literal del Proemio nos permitirá alcanzar interesantes revelaciones, como iremos viendo, y nos facilitará observar las características del estilo de Parménides, para lo cual escuchemos los primeros versos del Poema:

Las yeguas que me transportan, me iban enviando tan lejos como el deseo llegaba.

Se alude aquí a un deseo de llegar muy lejos, sin especificar qué deseo era este, y a que ciertas yeguas hacían posible que se alcanzara tal deseo. En los vv. 2-3 se habla de una vía o camino de cierta deidad, sin especificar, nuevamente, de qué vía ni de qué deidad se trata. Sólo se dice de aquélla que es $\pi$ o $\lambda \hat{v}-$

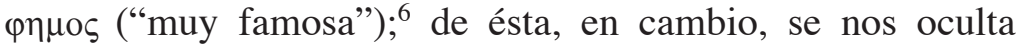
incluso si se trata de un dios o una diosa. Ahora bien: tales ambigüedades ¿pertenecen al estilo de Parménides o son meramente circunstanciales, debidas a la rigidez del hexámetro? Consideramos que han sido construidas por él con toda exactitud y esmero (recuérdese la cita de Bowra, al principio de este trabajo). Y a lo mejor una prueba de esto está en que, a la vez que nos pone dificultades, nos ofrece ciertas pistas o insinuaciones para resolverlas. Un ejemplo lo tenemos aquí mismo: si queremos saber cuál era el objetivo de ese deseo o anhelo que llegaba tan lejos, y hacia el cuál iban enviando las yeguas, los vv. 2-3 nos lo revelan, si los interpretamos adecuadamente:

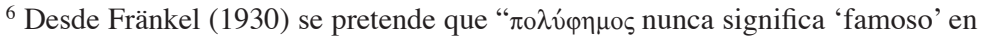
la antigua literatura griega" (L. Tarán, Parmenides. A text with translation, Princeton, Princeton University Press, 1965, p. 10). Pero esto lo desmiente Hesíodo, Erga, 760 ss. Esta referencia me fue señalada por Paola Vianello.
} 
pues anduvieron guiándome hacia $^{7}$ la vía muy famosa de la deidad,

"Andar guiando hacia" (v. 2) equivale a "ir enviando tan lejos" (v. 1), por lo que la otra ecuación entre ambos versos (es decir, el alcance del deseo y "la vía muy famosa de la deidad") se hace manifiesta. Y todavía el complemento del v. 3 da una pista para la identificación de dicha vía, pues dice de ella

...que lleva al hombre que sabe de cara a todas las villas, ${ }^{8}$

con lo que insinúa que es una vía elevada. Enseguida los vv. 4-5 hablan del éxito del recorrido de las yeguas:

por allí era conducido, pues por allí me conducían...

De aquí se infiere que el anhelo de alcanzar la vía divina era para recorrerla, lo cual fue finalmente satisfecho. Esto basta como muestra para definir el estilo de Parménides como deliberadamente ambiguo, desafiante e insinuador, cuyo propósito es inducir al lector a recibir el mensaje de su autor activa y laboriosamente, escuchando con oído atento; un estilo que presenta también distintas modalidades. Las ambigüiedades de sin-

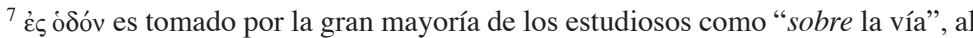
parecer porque piensan que la meta del viaje es la diosa que recibe al "joven", por lo que la óós debería estar antes de la llegada ante la morada de la diosa. Ya veremos que esto no es así.

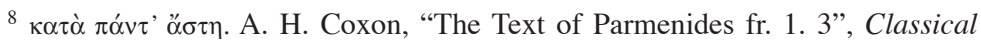

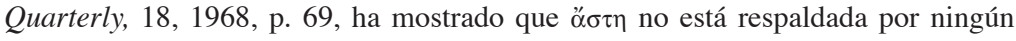
manuscrito, y que Diels la tomó de Mutschmann, quien a su vez la copió, come-

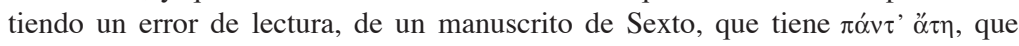

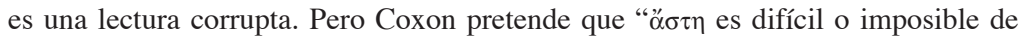
defender, pues no da buen sentido y es incompatible con 1. 27, según el cual la

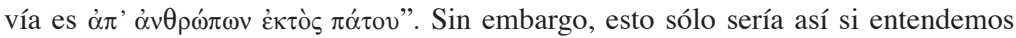

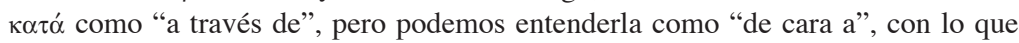

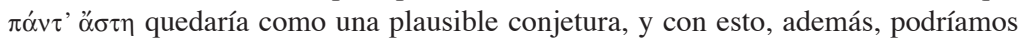
ver en los tres primeros versos del Proemio una cierta semejanza formal con los tres primeros de la Odisea. Esta sería sólo una de las varias reminiscencias de la Odisea que hay en el Proemio de Parménides.
} 
taxis a las que se refiere Gallop, y que son también deliberadas, se dan sobre todo en B1. 28-32 y en B2, pero no en el Proemio propiamente dicho (B1. 1-28 a).

Tal vez sea necesario agregar que, al lado de estas características de su estilo, el Proemio presenta un tipo especial de sutiles insinuaciones, cuya percepción nos permitirá alcanzar ciertas revelaciones inesperadas de la vida de Parménides y de cómo fue que nuestro autor decidió poner como introducción a un discurso filosófico una pieza literaria de carácter tan diverso.

Veamos ahora cómo estos primeros versos del Proemio tienen también otro enfoque, no narrativo, pero dispuesto también esmeradamente por Parménides. Nos referimos a cierto paralelo que puede captarse entre estos primeros versos de Parménides y los primeros de la Odisea,${ }^{9}$ en el primer verso de ésta el poeta homérico hace un elogio implícito de "el hombre $\pi$ o$\lambda$ $\tau_{\tau \rho} \pi \circ \varsigma$ " ("de muchas rutas", "de muchos recursos"); Parménides parece hacer lo propio con unas "yeguas $\pi \mathrm{o} \lambda \hat{\varphi} \varphi \rho \alpha \sigma \tau o \imath$ "10 ("muy atentas", "muy reflexivas", v. 4) que lo transportan y que contribuyen a realizar su deseo de llegar "tan lejos", hasta una vía divina que finalmente recorre con éxito. Ya veremos cómo el éxito de su aventura, al ser comparado con el fracaso que un personaje mitológico tiene en la suya, hace a aquéllas merecedoras del elogio insinuado. Incluso podemos conjeturar que nuestro autor, para hacer más sugestiva la insinuación de tal elogio, construyó la frase inicial de su Poema, ï $\pi$ лor $\tau \alpha i ́ ~ \mu \varepsilon$

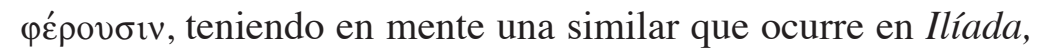

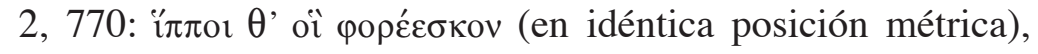

\footnotetext{
${ }^{9}$ Esto ha sido señalado por J. Mansfeld, op. cit., pp. 229-230, pero ha sido explotado por él de otra manera.

${ }^{10}$ Parménides parece haber dado con este singular adjetivo, no utilizado por ningún otro poeta griego antiguo, en su empeño por encontrar una palabra elogiosa para sus yeguas, que hiciera, además, pareja con el $\pi$ o $\lambda$ í de la voz pasiva (en su sentido de "muy atentas") o de la voz media (en el de "muy

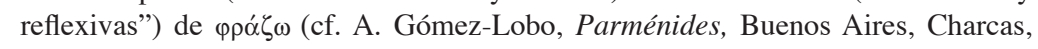
1985, p. 49).
} 
donde se hace un elogio, esta vez explícito, de los caballos de Aquiles. ${ }^{11}$

El enfoque narrativo al que hemos aludido más arriba nos indica que los cinco primeros versos de Parménides son un extracto del relato propiamente dicho, que comienza en el v. 6 . Esto muestra otra semejanza con la Odisea, cuyos diez primeros versos son un sumario del relato que sigue. Pero el paralelo con la Odisea no se detiene aquí. Cuando el héroe homérico llega al palacio de Alcínoo, el poeta le cede la palabra para que sea él quien relate sus aventuras desde la partida de Troya, para retomarla luego de su salida de la isla de los feacios. También en el Proemio Parménides introduce un juego entre dos voces, como si dos distintos narradores se disputaran la palabra. Y, además, tanto la Odisea como el Proemio de Parménides dan comienzo a su relato con un episodio avanzado de los sucesos. Todos estos detalles parecen ser "signos" que anticipan una relación muy estrecha entre el Proemio de Parménides y la Odisea, como iremos viendo.

Pero el enfoque narrativo de estos primeros versos nos tiene reservada otra revelación. De entrada, la frase relativa "las yeguas que me transportan" ( $\varphi \varepsilon ́ \rho o v \sigma ı v: ~ p r e s e n t e ~ h a b i t u a l ~ o$ iterativo) parece indicar una alusión de Parménides a yeguas de su propiedad, que usa a dondequiera que va y que en esta ocasión lo "iban enviando ${ }^{12}$ tan lejos...". Aquí puede notarse un paso abrupto de una vaga referencia a sucesos reales ("las yeguas que me transportan") a la narración de un suceso francamente fantástico ("me iban enviando tan lejos como el deseo

\footnotetext{
${ }^{11}$ Este paralelo lo señala Bernardo Berruecos Frank, El Poema de Parménides. Un acercamiento filológico, México, Universidad Nacional Autónoma de México, 2007, tesis de licenciatura, inédita.

${ }^{12}$ L. Tarán, op. cit., p. 10, pretende que todo el viaje de Parménides es repe-

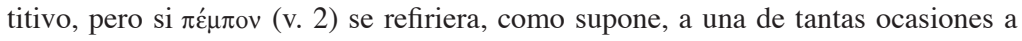

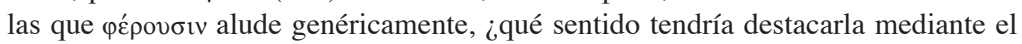
empleo del imperfecto, cuando el uso constante de verbos en presente a lo largo del Proemio habría sido más consecuente? ¿Qué sentido tendría destacar una ocurrencia que, por no ser única, no contiene nada digno de destacarse?
} 
llegaba, pues anduvieron guiándome a la vía muy famosa de la deidad"). Sus yeguas lo han traído, pues, de la realidad a la fantasía; y Parménides, el cochero, ha sufrido un cambio: podemos glosar sus lacónicas expresiones de esta manera: las yeguas que me transportan regularmente por donde yo las con-

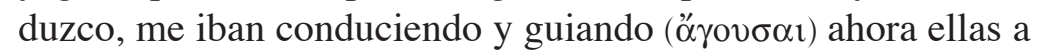
mí, pues "por allî” (v. 4), por un camino divino, "era yo conducido (

... pues por allí me conducían ( (é́pov) las muy reflexivas yeguas tirando del carro...

Este cambio abrupto de ámbito lo ha hecho pasar de una actitud alerta y vigilante a otra meramente expectante y pasiva. Todo esto nos sugiere que se trata con ello del tránsito natural de la vigilia al sueño. Para mayor abundamiento, podemos añadir que una ficción literaria no establece marcas entre el mundo real y el ficticio; si las hay, como es el caso, sólo puede tratarse del relato de un sueño. Parménides, al aludir a sus propias yeguas como aquellas que lo conducían en cierta ocasión por un camino divino, nos está insinuando que soñaba con ellas, y no lo dice directamente porque su poesía encierra el arte de la expresión indirecta, y porque, además, quiere concedernos el gusto de descubrirlo.

El Proemio parece, pues, ser o estar basado en la descripción de un sueño de nuestro filósofo, que debe haber constituido para él una magna y significativa experiencia; de lo contrario, no habría representado un motivo poderoso para hacérnoslo conocer. Pero veamos qué es lo que nos revela de su sueño la narración del Proemio.

\footnotetext{
13 "La anáfora del verso 4 ( que causa es relevante al contenido del texto, pues refuerza el hecho de que el коv̂pos "es llevado", no es él quien guía las yeguas". G. Ramírez Vidal, La Palabra y la Flecha (análisis retórico de textos de la Grecia antigua), México, Universidad Nacional Autónoma de México, 2005, p. 115.
} 
Ya hemos visto que se nos habla de un deseo o anhelo de alcanzar una célebre vía o camino divino que va elevado, y "que conduce ${ }^{14}$ de cara a todas las villas" de los hombres. Este deseo, que emergía con frecuencia en un cierto pasado, que ahora podemos determinar como el correspondiente a los días que antecedieron al sueño, se estaba ya cumpliendo oníricamente. Ahora bien: esta relación entre alusiones a sucesos reales (la vigilia) y referencias a acciones fantásticas (el sueño) se nos presenta como una oportunidad para recibir ciertas revelaciones de la vida de Parménides, quien, por lo pronto, nos ha dejado ver que tuvo un significativo sueño en cierto momento de su vida. Pero, ¿qué ocurría en los días previos a su sueño que fuera determinante para motivarlo? Hay en el relato dos referencias a estos días: la de unas yeguas que lo transportan en sus recorridos habituales en el mundo real, y la de un deseo que lo embargaba supuestamente (ahora lo inferimos) durante tales recorridos. Lo demás de su relato son referencias al ámbito de su sueño.

Tal vez nos ayude a indagar lo que ocurría en tales días la consideración de la época en la vida de nuestro autor en que pudo embargarlo tal deseo o impulso, que como hemos visto era el de alcanzar una elevada vía divina para recorrerla. Tal anhelo o ilusión es propio de un mozuelo de unos trece o catorce años, que sería, además, dueño de unas yeguas que sabía conducir desde un carro, y que, podemos suponer, por pertenecer a una familia acomodada, ${ }^{15}$ su padre le había regalado para que paseara o hiciera algún servicio con ellas a la comunidad

\footnotetext{
${ }^{14}$ No me parece que tenga razón C. M. Bowra (p. 109) al rechazar ỏ ós como

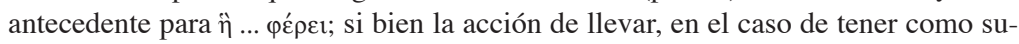
jeto un camino, se entiende comúnmente en el sentido intransitivo de "llevar a algún lugar", y no en el sentido transitivo de "llevar a alguien", en el caso del Proemio cabe muy bien este último, puesto que no se trata de un camino común y corriente, que puede llevar a cualquiera (razón por la cual la transitividad es en tal caso irrelevante), sino de uno muy especial, que sólo lleva "al hombre que sabe" ( $\varepsilon i \delta o ́ \tau \alpha \varphi \hat{\omega} \tau \alpha)$.

${ }^{15}$ Diógenes Laercio, IX, 21-3. Testimonio A1 en Diels-Kranz.
} 
de Elea. Y en tales recorridos iría naciendo en él el gusto y satisfacción de servir a sus conciudadanos, lo que pronto se trocaría en el deseo o anhelo ( $\theta v \mu o ́ s$, v. 1) de ofrecer algún día, y de alguna manera, un magno servicio, esta vez a la Hélade entera. Esto, por asociación de ideas, podría haberle traído a la memoria la imagen de Faetón, ${ }^{16}$ el intrépido muchacho que, intentando la magna pero exorbitante empresa de conducir el carro de su padre el Sol para alumbrar el mundo, sucumbió bajo el rayo de Zeus. Y Parménides, a la sazón un jovenzuelo como Faetón, volviendo su vista hacia lo alto durante sus recorridos, no dejaría de recordar el triste fin de su personaje predilecto, pensando tal vez: "si tú, Faetón, en vez de la imprudencia de conducir los brutales caballos de tu padre Helios hubieras llevado para el efecto un carro y unas yeguas como las mías...". Y los motivos estaban dados: esa noche tuvo un sueño... Parménides, en su sueño, se identificaba con Faetón, pero era un Faetón más prudente, aunque tan intrépido como aquél. ${ }^{17}$

Aclarado así cuál es la vía muy famosa de la deidad, pasemos a considerar la segunda sección del Proemio, que se inicia en el v. 6. Hay que observar, en primer lugar, que esta segunda parte presenta, por un lado, la particularidad de la aparición de detalles técnicos y descriptivos, que no son, por lo demás, meramente esto, y cuyo fondo se verá más tarde, y por otro, una sutil característica: nos referimos a que una segunda voz, que parece superponerse a la primera, imponiéndose, toma a su cargo el relato entre los vv. 6 y 21, antes de que la primera vuelva a escucharse pronunciando los restantes versos del

\footnotetext{
${ }^{16}$ De acuerdo con Bowra, la historia de Faetón debió haber sido bien conocida en tiempos de Parménides.

${ }^{17}$ Esta misma intrepidez se revelará todavía cuando nuestro joven sea ya un filósofo consumado; como se verá después, no se contentará con que su pensamiento añada una más a la lista de las "opiniones de los mortales", aunque la suya fuera "la más semejante a la verdadera", según el dicho de Jenófanes (B 35) que sin duda Parménides tenía en mente, sino que su intento apuntará al "corazón imperturbable de la Verdad bien redondeada".
} 
Proemio (vv. 22-28 a). Esta segunda voz es la que introduce los detalles técnicos y descriptivos a que nos hemos referido, y la denominación de las puertas como "de los caminos de la Noche y del Día" (v. 11), puntos que no tienen que ver directamente con la narración del sueño de un joven quien no ha tenido aún escrúpulos filosóficos. Y esta voz se distingue de la primera, aparte de esto, en que parece delatar la presencia de un narrador que observa los sucesos a distancia, como no involucrado ya en lo que sucede, y esto puede apreciarse en que el pronombre $\mu \varepsilon$, que se halla tres veces en los cinco primeros versos, no aparece ninguna entre los vv. 6 y 21. Incluso la llegada ante las puertas (v. 11) no es referida con algo como "y llegamos ante unas puertas", netamente narrativo, sino mediante una frase con verbo en presente intemporal: "ahí están las puertas..." Esta ausencia deliberada de la primera persona salta a la vista en otros dos pasajes de esta segunda sección del Proemio: el primero es el de los vv. 6-10, donde se relata que el eje del carro lanzaba un silbido resonante,

... mientras ${ }^{18}$ se apresuraban a enviar

las jóvenes Helíades, abandonando las moradas de la noche, hacia la luz ${ }^{19} \ldots$

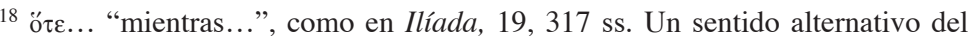
vocablo ("cada vez que") puede aplicarse a una segunda lectura del Proemio, como veremos.

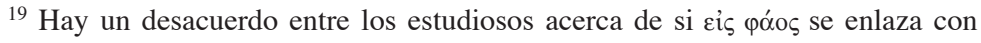
$\pi \varepsilon ́ \mu \pi \varepsilon ı v$ (v. 8) o con $\pi \rho \circ \lambda ı \pi \circ \hat{\sigma \alpha}$ (v. 9), y los que lo enlazan con este último verbo

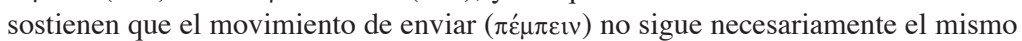
sentido que el de haber abandonado previamente. Pero el problema no está en esto, sino en determinar a qué "moradas" se refiere aquí Parménides, ya que, si se trata de "las horrendas casas de la tenebrosa Noche" de Hesíodo (Teogonía, 744745), que son ocupadas alternativamente por la Noche y el Día (id., 748-754), y las Helíades las han abandonado "hacia la luz", ¿cómo es que había luz del Día fuera de la casa mientras ellas, que son la personificación de los rayos del Sol, han permanecido dentro? Es decir, ¿cómo es que han retrasado su salida, si les tocaba haber salido con el Día para integrarse a su padre Helios, y así poder éste alumbrar el mundo? Y no sólo esto: tal retraso en la salida de las doncellas solares, además de ser del todo incomprensible, implicaría que habían estado, entretanto,
} 
El v. 2, que narra el mismo suceso, pero que dirige nuestra atención hacia las yeguas, dejando de momento en la sombra la acción de las Helíades, hace una referencia explícita a la primera persona: "pues anduvieron guiándome hacia la vía muy famosa...", es decir, "hacia la luz" (v. 10). Además, el narrador del v. 2, que vive el momento que relata, parece efectuar su relato desde el carro que ocupa, pues lleva su mirada hacia delante, hacia donde lo van guiando ("丷ovovol) las yeguas, mientras el de los vv. 8-10 parece ver lo que relata a distancia, mirando de canto el cortejo formado por las doncellas, las yeguas y el carro volando por el aire (como lo sugiere un sueño), lo que le permite ver tanto adonde el cortejo va (عiऽ póos, v. 10), mirando hacia un lado, como lo que ha queda-

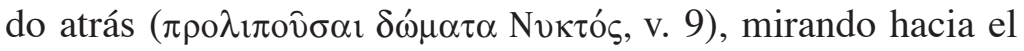
otro. El segundo pasaje es el de los vv. 20-21, inmediatamente después de que Díke, la guardiana de las puertas, acaba de abrirlas:

...por allí, en fin, a través de ellas,

fueron llevando, derecho, las jóvenes el carro y las yeguas por el ancho camino.

Aquí también puede captarse que el narrador relata viendo la acción de canto y a distancia. Compárese esto con los vv. 4-5, que refieren el mismo momento:

Por allí era (yo) conducido, pues por allí me conducían...

\footnotetext{
compartiendo insólitamente la casa con la Noche. De este modo, sólo podían haber abandonado la casa hacia la oscuridad, es decir, estando la Noche afuera, cuando a su padre y al Día les tocaba descansar. Y esto fue lo que, efectivamente, hicieron al decidir ir en busca de Parménides, si bien tal acción previa no está narrada, sino sólo implícita, en el relato. Y lo que se narra en este pasaje (vv. 6-10) corresponde a un episodio posterior, cuando las "moradas de la noche", que han quedado atrás al ser abandonadas por el cortejo de Parménides "hacia la luz", son ahora las que la Noche, llevando en sus brazos a Hipnos (Teog., 756), comparte simultáneamente con los mortales.
} 
Aquí el primer narrador se identifica con el cochero, pues, como en el caso del narrador del v. 2, se siente que vive el momento que relata.

Aquella distancia desde la que relata el segundo narrador puede ser temporal además de espacial.

La emergencia repentina de la primera voz, al ser escuchada nuevamente volviendo a hablar en primera persona en los vv. 22-23, y en un momento en que el relato está ya avanzado, nos sugiere que este primer narrador había seguido su relato, desde el v. 6, dando su propia versión puramente narrativa, como había hecho en los vv. 1-5, pero que entonces el segundo narrador, como llevándonos aparte con él, impone su voz, apagando la del primero, y tomando ahora a su cargo la narración de los sucesos desde el v. 6 hasta el v. 21, como hemos visto; y que, hecho esto y habiendo ya cumplido su cometido, sea cual éste fuera, nos conduce nuevamente junto a aquél para que sigamos escuchando su narración, que no había sido interrumpida por él.

Esto sugiere que había, entre los "papeles" de Parménides, un breve poema previo y separado, en el que su autor, aquella primera voz, revelaba el seductor y sugestivo sueño que había tenido en su primera juventud y que ahora, años después, el adulto y ya filósofo Parménides retomaba, haciéndole algunos ajustes y complicaciones (= la segunda voz) para integrarlo al poema filosófico que estaba preparando. Y esto desea revelárnoslo con el insinuante y sutil juego de las dos voces: la del joven que relata en hexámetros su sueño, y la del adulto que trabaja en el arreglo de tal relato para enlazarlo al poema filosófico y posterior, como una introducción a él.

Tal diversidad de origen de los dos poemas explica el asomo de desconcierto que, con razón, han mostrado algunos estudiosos respecto de la relación que un relato fantástico pueda tener con un discurso filosófico, a lo que nos referimos más arriba. ${ }^{20}$

${ }^{20}$ Véase nota 5. 
Este enlace, donde el breve poema previo se transforma en el proemio del poema filosófico, nos hace recordar aquellos días que precedieron al significativo sueño del joven que anhelaba, en sus recorridos con sus yeguas, prestar (algún día) un magno servicio a toda la Hélade. Y este anhelo o impulso

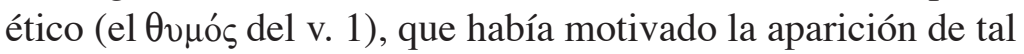
sueño, y que persistió después durante años como un segundo "sueño" que tenía en el primero su propia representación simbólica, estaba fructificando y concretándose ahora en la elaboración de un discurso filosófico cuyo propósito último sería iluminar a los mortales, sus semejantes, con la luz de la Verdad.

Veamos ya cuál es el detalle del relato de aquel sueño, aunque modificado por los ajustes y complicaciones introducidos por la "segunda voz" de nuestro autor. El episodio con que comienza su relato (vv. 6-10) esta segunda voz, no es, con seguridad, el episodio con que comenzaba el sueño, pues las doncellas hijas de Helios, abandonando ya las "moradas de la noche", de donde se supone que acaban de sacar a Parménides, que dormía en una de ellas, se apresuraban a enviarlo, con su carro y yeguas, hacia la luz, es decir, hacia Oriente, donde una tenue luz empezaba a insinuarse. Éste sería el segundo episodio del sueño. El primero, el que inicia el sueño y que no está relatado, es cuando el joven, durmiendo en su lecho, sueña que es despertado por unas jóvenes que cubrían su radiante rostro con unos velos, y quienes lo urgían a preparar las yeguas y el carro para salir de inmediato. El segundo episodio del relato (v. 11), y tercero del sueño, es la llegada ante unas puertas:

Ahí están las puertas de los caminos de la Noche y del Día.

Se trata de las puertas de la Aurora, en el confín oriental del mundo, pero aquella "segunda voz" las denomina "de los caminos de la Noche y del Día”. Esto es un eco de Odisea, X, 
86, que más tarde explotaremos, pero es también algo más que esto. Siguen dos versos de detalles descriptivos (vv. 12-13):

A ellas sostiene en sus extremos un dintel y un umbral de piedra; ${ }^{21}$ etéreas ellas mismas, se llenan con grandes hojas.

Volveremos después sobre ellos, que son añadidos que se han insertado con miras al enlace del relato previo con el discurso filosófico que le sigue. Sólo sugeriremos ahora que el ser etéreas ellas mismas no se refiere a que estén localizadas en el cielo, sino a su contextura. ${ }^{22}$ Luego (v. 14), se nos hace ver que la severa Díke, la Justicia que guarda el orden cósmico, es la guardiana de las puertas de doble hoja. Esto parece ser también un añadido al relato original del sueño, que complica la trama al introducir un elemento discordante, el cual debe ser superado por las Helíades (vv. 15 ss.):

Engañándola ${ }^{23}$ con suaves palabras, las jóvenes

la persuadieron hábilmente de que para ellas el pasador asegurado quitara pronto de las puertas...

Díke representa un obstáculo que las Helíades deben superar, pues son ellas las que promueven el viaje y tienen que persuadirla para lograr que abra las puertas de par en par y permitir que el joven con todo y carro y yeguas las trasponga. A continuación se relata la apertura de las puertas, con el curioso

\footnotetext{
${ }^{21}$ Que este umbral sea de piedra parece insinuar que no se trata de las puertas de la casa de la Noche hesiódicas, cuyo umbral es de bronce.

22 "Ellas mismas", consideradas separadamente de sus hojas, son la capa delgada de aire limitada por el marco de la puerta. "Etéreas" sería aquí "formadas de aire".

${ }^{23} \Pi \alpha \rho \varphi \alpha ́ \mu \varepsilon v \alpha \imath$ por lo regular es entendida como "apaciguándola”, "aplacándola", "hablándole". W. K. C. Guthrie, A History of Greek Philosophy, Cambridge, Cambridge University Press, 1965, vol. 2, p. 8, la toma en su matiz de "engañar", pero no lo comenta. Con este mismo matiz aparece en Odisea, XVI, 286-287: $\mu \alpha \lambda \alpha$ -

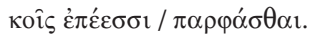


detalle descriptivo del gran abismo que crean las hojas al separarse. Pero sobre todo nos llama la atención la referencia (vv. 19-20) al giro alternado de los ejes de las hojas, señalando que están "ajustados con clavijas y pernos", expresión que sustituye sordamente a la correspondiente a su rechinido explícito. Un pasaje de la Odisea (XXI, 47) habla del rechinido de unas puertas comparándolo con el mugir de un toro. ¿Por qué Parménides calla el rechinido de sus puertas? ¿Quiere probar el oído sutil de su lector? Luego veremos por qué lo hace. ${ }^{24}$ Este sonido de la apertura de las puertas, insinuado solamente, nos hace pensar en otros "sonidos" insinuados antes (vv. 15-17), cuando las Helíades deben persuadir a Díke pronunciando palabras suaves y hábiles. Hay que considerar aquí que, aunque Parménides omite en su relato varios episodios de la trama que aquella "segunda voz" ha urdido, complicando los sucesos de su sueño, no deja de tenerlos en mente, y uno de ellos es el momento de la pronunciación de aquellas "suaves palabras”. ¿Cuáles son éstas? ¿Cómo persuaden a Díke las hijas de Helios? Esta cuestión debe ser planteada y resuelta en respuesta a la actitud desafiante que se trasluce en la parquedad de estilo de Parménides. Las dos palabras que hemos resaltado: $\sigma \varphi \iota v$ ("para ellas") y $\alpha ં \tau \varepsilon \rho \varepsilon ́ \omega \varsigma$ ("pronto") dicen algo acerca de esto. Díke, la justicia cósmica, distinta de la Díke del v. 28, que junto con Thémis representan la ley y la justicia humanas, se relaciona con potencias cósmicas cuyo paso controla, por lo que no permitiría el paso por las puertas a ningún mortal, y sólo lo haría con las Helíades; éstas, por consiguiente, solicitan la apertura de las puertas "para ellas", no para el joven ni para las yeguas, y además, "pron-

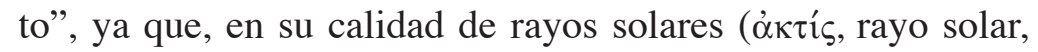
es femenino en griego), deben reintegrarse a su padre Helios

\footnotetext{
${ }^{24}$ Un sonido que puede confrontarse con este de las puertas es el silbido resonante del eje del carro (v. 6), al que sí hace Parménides una referencia explícita. En su momento veremos qué relación hay entre ellos.
} 
cuanto antes, pues éste está próximo a salir por las puertas de la Aurora para alumbrar el mundo. Según todo esto, Díke no abriría las puertas de par en par, como acabó haciéndolo, finalmente, sino sólo lo suficiente para dejar pasar a las Helíades. Faltaba, pues, algo en la labor de éstas para convencer a aquélla de dejar pasar, al menos, el carro y las yeguas, con lo que el joven pasaría también. Díke, la justicia cósmica, guardiana de las puertas de la Aurora, no entiende de leyes ni de justicia humanas, por lo que las doncellas solares no debían mencionar al joven, sino más bien protegerlo de la severa Díke, interponiéndose entre ésta y aquél, ocultándolo así a su mirada. ¿Qué debían, pues, decir a Díke para hacerla abrir las puertas de par en par? ¿Cuál era el dicho "hábil” que se requería? No había más que uno: que el carro y los corceles que traían eran los de su propio padre, quien se los había entregado durante el crepúsculo del día anterior para atender a cierta emergencia (en esto consistía el engaño [v. 15]). Y Díke, contrariada pero apremiada también por la hora que era, abre las puertas de par en par (vv. 20 ss.).

$\ldots y$ por allí, en fin, ${ }^{25}$ a través de ellas,

derecho, fueron llevando las jóvenes el carro y las yeguas por el ancho camino.

Con esto, aquella "segunda voz", la del adulto y ya filósofo Parménides, que hace ajustes a su poema previo para adaptarlo como proemio a su poema filosófico que ya prepara, da por terminado su relato refiriéndose al momento final, culminante y exitoso de la aventura: el recorrido luminoso por el camino de Helios, llevando la luz al mundo. Y ahora esta "segunda voz" calla, dejando oír la primera, la del joven poeta que relata su sueño y que en ese momento de su relato (vv. 22 ss.) se refiere, sin duda, a un suceso anterior al que acabamos de

\footnotetext{
${ }^{25} \dot{\rho} \alpha . .$. Denniston, The Greek Particles, Oxford, Clarendon Press, 1970, p. 45.
} 
escuchar, por más que pareciera lo contrario. Y es que Parménides, el adulto, a más de ser "exacto" (recordando el juicio de Bowra) al emplear la partícula $\dot{\rho} \alpha$ (= "en conclusión", v. 20) que alude al suceso final de su aventura, es también un poco "perverso" (recordando ahora a Gallop) al emplear enseguida la expresión sutilmente ambigua $\delta$ ' $\alpha$ v่́c $\omega v$ ("a través de ellas") para inducirnos a pensar erróneamente que, puesto que las puertas acaban de ser abiertas, son atravesadas por el joven y su cortejo por primera vez, es decir, hacia allá, hacia el confín del mundo, donde se encuentran la Aurora y el Sol en ese momento; pero, bien mirado, no puede ser ése el sentido en que se atraviesan las puertas en esta referencia, y enseguida también nuestro no tan "perverso" autor nos lo hace ver (v. 21), ya que hacia allá no se puede ir "derecho, por un ancho" y largo camino, como lo sugiere el imperfecto é $\chi 0 \mathrm{v}$ ("fueron llevando"); por ello, el sentido en que se atraviesan aquí las puertas es hacia acá, es decir, de regreso y por segunda vez, para así ya ir "derecho", hacia arriba, por el largo y "ancho camino" de Helios. De este modo, el paso a través de las puertas hacia allá no está relatado, aunque sí implícito, en la narración. Por eso es que vemos en el v. 22 el relato retrospectivo de lo que ocurre una vez que el joven pasa con su escolta hacia allá, antes del episodio final de la aventura:

...y la diosa me recibió con benevolencia...

Lo anterior pertenece al relato previo del sueño de nuestro joven, cuya "primera voz" recupera aquí la palabra al hablar en primera persona nuevamente.

Con esto queremos hacer notar una segunda faceta del estilo de nuestro filósofo, quien en ciertos pasajes, como los vv. 20-21, gusta de ponernos ante alguna dificultad, en este caso la sutil ambigüedad del "a través de ellas", para incitarnos a trabajar activamente en la interpretación de lo que nos 
dice, primero percibiendo la dificultad y enseguida resolviéndola, pues en cada caso nos da las claves para ello.

La "diosa", entonces (esta diosa sólo puede ser aquí la Aurora, $E a$ ), recibe al joven dentro de su sueño y le dice, después de tomar su mano derecha con la suya:

¡oh, joven, compañero de inmortales aurigas,

que alcanzas nuestra morada con las yeguas que te transportan, salud!, pues no es un mal hado ${ }^{26}$ el que te envía

a volver por este camino (que está apartado de los pasos de los hombres), sino Thémis y Díke...

Si esta Díke fuera la misma que la severa guardiana de las puertas (v. 14), habría aquí un conflicto, pero se trata ahora de la justicia humana, que ha inducido en el ánimo del joven, podemos suponer, el deseo o anhelo de llegar "tan lejos" (öбov, v. 1).

Y después de estas palabras de la diosa, el poema de juventud, que cantaba el delicioso y significativo sueño, continuaba el relato, debemos suponer, con el momento en que el joven recibía en su ser el resplandor solar, seguido en fin del que lo presentaba recorriendo el "ancho camino" de Helios, alumbrando el mundo. Pero el relato que en definitiva nos deja el ya adulto y filósofo Parménides, en su intento de adecuarlo al discurso que sigue, suprime la referencia a aquel momento y anticipa la del recorrido por el camino divino mediante la sutil y sabrosa ambigüedad del "a través de ellas". ¿Por qué ha procedido de esta manera? Probablemente no tenía intención de publicar el poema compuesto en su juventud, pero ahora que ya tenía el propósito de presentarlo como la primera parte de su poema filosófico le asaltaba el temor de parecer pretensioso o

\footnotetext{
${ }^{26}$ Aquí la diosa recibe al nuevo "Faetón" anticipándole su éxito, puesto que viene con sus propias yeguas, muy atentas ( $\pi \circ \lambda \hat{v} \varphi \rho \alpha \sigma \tau o \imath)$ al camino (a diferencia de los brutales caballos de Helios, que se salen de él), y recordando el hado funesto que perdió al primer Faetón. Ahora un buen hado envía a este segundo Faetón a "volver"

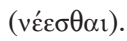


soberbio al aparecer ante sus lectores como el Sol que ilumina el mundo y a los hombres, y prefiere callar la referencia al primero de esos momentos y retrotraer la del segundo para, enseguida de referir las palabras de la Aurora al joven, dejar el terreno allanado a su lector e inducir a éste a restituir lo que allí había. ${ }^{27} \mathrm{Y}$, además, aprovecha esto para colocarnos ante un nuevo problema: ¿cómo ha adquirido el joven, el nuevo "Faetón", el resplandor que se requiere para alumbrar el mundo? La discreta luz de la Aurora, la diosa que le ha dado la bienvenida, no es suficiente; el Sol, su padre, no dispone aún de sus rayos, que están personificados en las Helíades; son, pues, éstas las que, integrándose a él y ya no a su padre, le confieren aquel resplandor. Y así, atravesando las puertas hacia acá, fueron llevando al joven las "muy atentas" (al camino) y elogiables yeguas "por el ancho camino", ${ }^{28}$ con lo que quedaría restituido, al menos en idea, lo que allí había.

Así terminaría el relato del sueño del joven Parménides. No sabemos de cuántos versos constaba el poema de juventud, que era un poema independiente y cerrado. Pero ahora el adulto Parménides lo presenta, con los ajustes y añadidos a los que nos hemos referido y con las alteraciones y truncamientos que acabamos de ver, en veintiocho versos, el último de éstos incompleto. Y enseguida, completando el verso, nos sorprende con una frase que pertenece ya al poema filosófico: "es necesario que te informes de todo", y que, incluso, da la impresión de no ser la primera de dicho poema, ya que, después de otros

\footnotetext{
${ }^{27}$ Tal vez esto parezca demasiado intrincado para formar parte de la interpretación de un texto, pero considero que Parménides deseaba compartir con su lector el problema existencial que le preocupaba.

${ }^{28}$ Esto evidencia que lo que relata el v. 21 no sólo está retrotraído, sino además un tanto desarreglado, ya que el temor de parecer soberbio hace que nuestro poeta desencaje a las Helíades de su integración al joven para colocarlas "conduciendo el carro y las yeguas por el ancho camino"; pero si restituimos la mencionada integración y reconocemos a las yeguas como las únicas conductoras del resplandeciente joven, se comprende mejor el elogio que se hace de ellas, como hemos visto, en los primeros versos del Poema.
} 
cuatro versos que la siguen y que conocemos como B1. 29-32, leemos enseguida (dispuesto por H. Diels como Fr. 2. 1) lo que probablemente Parménides mismo colocó allí, y que suena más a inicio de un discurso:

Pues bien, yo hablaré; tú, en tanto, nutre ${ }^{29}$ el discurso, tras haber escuchado.

Aquí podemos encontrar cierta curiosa simetría en la conexión entre los dos poemas: el primero de ellos queda trunco al final, pues el relato del último episodio es retirado de su lugar correspondiente en la secuencia de la narración para ser colocado varios versos atrás; y el segundo queda trunco al inicio, cuando el verso que debiera abrir el discurso filosófico es colocado varios versos adelante (B2. 1). Podemos observar también que nuestro filósofo da fin al primer poema y comienzo al segundo en el hemistiquio de un verso (B1. 28). ¿No podía, acaso, haber completado este verso alargando, de alguna manera, su primera mitad para iniciar en el siguiente, con un verso también completo, el poema filosófico? Es probable que no haya procedido así para no dar la impresión de que, una vez terminado felizmente el poema que relataba su sueño de juventud y habiendo cumplido su deseo de revelárnoslo, lo que venía a continuación pudiera dar la apariencia de ser algo de otra naturaleza. Por ello, toma con una mano, por decir así, el extremo final del poema de juventud original, ya con los ajustes hechos, y con la otra el extremo inicial original del poema de madurez para, con un fuerte "golpe", encajar uno en el otro; y el punto

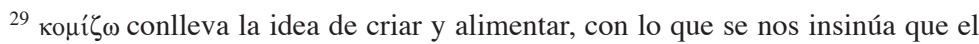
discurso que sigue es como un polluelo o como un bebé, que nacen sin estar bien desarrollados; por lo tanto hay que "nutrir" al bebé, aclarar el sentido de sus balbuceos, de las ambigüiedades de su sintaxis, agregar las palabras faltantes, para tener así la formulación bien desarrollada y poder también entenderla coherentemente. Esto puede observarse, sobre todo, en B1. 31-2, B2 y B6. Y aquí hay una nueva faceta del estilo de nuestro autor, que no se observa en el Proemio, una nueva modalidad con que nos pone a trabajar, a recibir activamente su mensaje.
} 
de encajadura sería el verso 28, que quedaría así incrustado en su mitad por ambas puntas; y las "astillas" que saltaran serían acomodadas donde mejor cupieran, antes y después de tal encajadura; de ahí que el final del primer poema y el comienzo del segundo quedaran un tanto desacomodados, como hemos visto. Con esto nuestro autor quiere darnos a entender que los dos poemas distintos dejan de serlo para conformar ahora un solo y mismo poema de naturaleza y sentido filosóficos.

Estas consideraciones nos sugieren que Parménides, ya como el adulto filósofo, quiere que volvamos atrás con una nueva lectura de la primera parte:

Pues bien, yo (el filósofo) hablaré30 (ahora)...(B2. 1)

Aquí es oportuno volver sobre algo que habíamos dejado pendiente. Decíamos que al referir la apertura de las puertas (vv. 17-20), Parménides omite intencionalmente la mención a su rechinido. Con esto quiere probar el oído atento del lector. Antes había referido explícitamente el silbar agudo y resonante del eje del carro. Esto lo oyeron, podríamos decir, nuestros oídos externos, pero ahora el rechinido de las hojas de la puerta lo escucha nuestro oído interno, al atender a la descripción de su engranaje. Decíamos también que los detalles descriptivos del relato no eran meramente eso, sino que había en ellos cierto fondo significativo. El doble rechinido de las hojas tiene el sentido de un doble canto, una doble lectura que puede hacerse de distintos pasajes del Poema, y uno de ellos es lo que ahora llamamos la primera parte (= el Proemio).

En esta segunda lectura, esta primera parte, que ya no es la descripción de un sueño, cambia de "aspecto". Sus elementos figurativos, que años atrás tenían un aspecto físico y exterior,

\footnotetext{
${ }^{30}$ Este "yo" ya no es el "joven" que relata su sueño; tampoco es "la diosa" que dirige al joven las palabras de bienvenida, palabras que parecen continuarse con las del discurso filosófico. Esto es una trampa en que nos ha hecho caer el un tanto "perverso" Parménides.
} 
adquieren ahora uno simbólico e interior, al servir al relato de una aventura del pensamiento, al relato que canta la aventura triunfal del espíritu de Parménides en su búsqueda ardiente

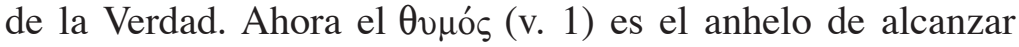
la vía de esta deidad interior, aquella vía que "es camino de persuasión (pues la Verdad lo sigue)", ${ }^{31}$ B2. 4, y "que lleva al hombre que sabe...", B1. 3. Esta relación entre B1. 1-3 y B2. 3-4 es una muestra significativa de que ambos poemas "encajan".

Antes de seguir adelante debemos referirnos a otro de los ajustes o añadidos hechos por la "segunda voz". Habíamos visto que el v. 13 especifica que las puertas mismas, etéreas, se llenan con grandes hojas. En esto se puede percibir una sutil distinción entre "las puertas mismas" y sus hojas. El v. 12 parece, por el contrario, identificarlas, al señalar que "están sostenidas en sus extremos por un dintel y un umbral..." Incluso podemos decir que la pluralidad de dichas puertas en este verso está dada por las dos hojas. Pero el v. 13 insinúa que tal pluralidad está dada por "ellas mismas". ${ }^{32}$ Esta aparente inconformidad entre los dos versos no debe desconcertarnos demasiado. Se trata de una muestra más del estilo parco y desafiante de Parménides, quien gusta de ponernos en aprietos a cada paso. Ya hemos visto, ${ }^{33}$ al toparnos con las "moradas de la noche" (B1. 9), cómo hay dos tipos de ellas, y cómo cada tipo tiene su momento en el desarrollo de la trama, aunque no todo momento de ésta tenga una referencia explícita en el relato, como ya hemos visto en este y en otros casos. Se trata ahora de dos tipos de puertas. El v. 12 hace referencia a las puertas

\footnotetext{
${ }^{31}$ Éste sería ahora "el camino de la deidad, que lleva al hombre que sabe". Ahora el antecedente para "que lleva" sería "la deidad" y ya no "el camino", por lo que no aceptamos la modificación de Bywater al insertar una iota suscrita a 'A $\lambda \eta \theta \varepsilon i ́ \eta$ ('A $\lambda \eta \theta \varepsilon i ́ n)$, entendiendo que es el camino el que sigue a la Verdad y no a la inversa.

${ }^{32}$ Véase nota 22.

${ }^{33}$ Véase nota 19.
} 
que corresponden a las imágenes evocadas por la narración; son las puertas que dan acceso a la morada de la diosa. El v. 13 , en cambio, alude a una variedad de puertas que no trascienden el texto mismo, o que lo trascienden en otro sentido. Se corresponden con ecos o reminiscencias de pasajes de otros textos, y son "puertas" porque invitan al lector a "atravesarlas" para "recorrer" con oído atento (= sus propias yeguas) y con visión inquisitiva (= sus propias Helíades) dichos pasajes, a fin de relacionar sus contextos evocativos con los de Parménides. Ya veremos en qué caso representa esta correspondencia de contextos un hábil recurso de Parménides para enriquecer e ilustrar las insinuaciones y sutilezas con que se expresa.

Volvamos a la segunda lectura de la primera parte del poema filosófico integrado, pues Parménides tiene algo importante que decirnos, ahora ya como el pensador que ha alcanzado la Verdad en la intimidad de su pensamiento, y que quiere comunicárnosla, de acuerdo con aquel abstracto anhelo de su primera juventud, deseando ofrecer un magno servicio a toda la Hélade... y a toda su posteridad, agregaríamos nosotros. Y esta comunicación nos va a revelar la manera como la alcanzó, lo que es al mismo tiempo una invitación a imitarlo en ello.

Nuevamente los cinco primeros versos son un sumario o extracto de lo que se relata después. "Las yeguas que me transportan", de acuerdo con el nuevo "aspecto" del relato, son el oído atento o interior 34 "que me lleva" (habla Parménides o, incluso, el mismo lector, que debe emularlo) por un texto, o por ciertos textos que exponen doctrinas u "opiniones de mor-

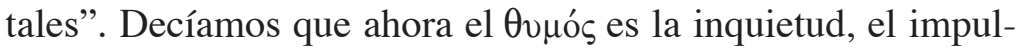
so que lo mueve a la búsqueda de la Verdad; es el deseo de ver claro (= las Helíades, que en su ansia de luz se despojan de los "velos" que cubren sus cabezas), que marca el rumbo

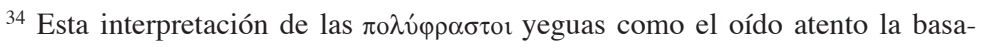
mos en la fina capacidad auditiva de los caballos, que sin duda era conocida desde antiguo.
} 
que debe seguir el oído atento (= las "muy atentas yeguas"), conduciendo al entendimiento (= tirando del "carro"), cada vez que (ö $\tau \varepsilon$, v. 8$)^{35}$ aquéllas se apresuran a enviarlas, "abandonando las moradas de la noche" (= "las opiniones de los mortales"), en busca de la luz... Puede percibirse en este pasaje (vv. 6-10) cierto paralelismo con B1. 28-32, en el comienzo del discurso filosófico compuesto años después de aquel poema de juventud. Parménides, teniendo en mente B1. 6-10, componía B1. 28-32: "es necesario que te informes de todo", nos dice, exhortándonos a imitarlo; "por un lado (en la luz que hay que alcanzar), está el corazón imperturbable de la Verdad...; por el otro (en las "moradas de la noche"), las opiniones de los mortales", o sea, el corazón perturbable de éstas, que no están bien redondeadas, como lo está aquélla. Hay, pues, que escuchar "todo", llevando nuestras "yeguas" (nuestro oído atento), por "caminos" discursivos ya trazados por otros "caminantes" o "cocheros", escuchando con atención lo que ellos toman por la Verdad. Lo que dice Parménides a continuación (B1. 31-32) $)^{36}$ es quizá la respuesta lanzada a algún amigo pi-

\footnotetext{
35 Véase nota 18.

${ }^{36}$ Este célebre y controvertido dístico es, sin duda, la mejor muestra de las ambigüedades de sintaxis que hay en el poema parmenídeo, y uno de los ejemplos que hay en él de una frase elíptica. Esto estuvo cerca de verlo H. Diels, al

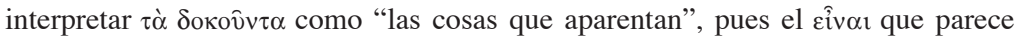
completar la frase, y que nosotros "vemos" en la elipsis de la expresión, lo encontró explícito en el v. 32: "las cosas que aparentan... ser". Pero al desligar દî̀ $\alpha_{\iota}$ de

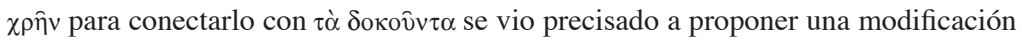

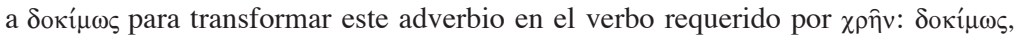

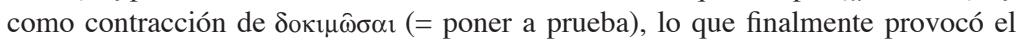
rechazo casi general a su interpretación. Pero, en mi opinión, Diels iba en la dirección correcta: el pasaje es polémico en su contenido, y parco hasta la elipsis en su forma, en su estilo "casi telegráfico", según expresión de N. L. Cordero. Esto nos recuerda lo apuntado acerca de B2. 1 (véase nota 29). Este sería uno de tantos

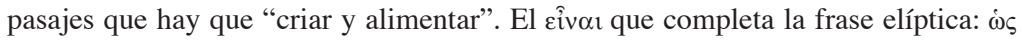

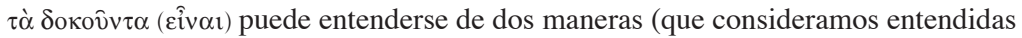
así por Parménides mismo) que dan lugar también a dos lecturas distintas de B1. 31-32 (recuérdese lo dicho acerca del "canto" de las dos hojas de la puerta, al girar
} 
tagórico que, al enterarse de lo que estaba escribiendo, le preguntaría con extrañeza: ¿y por qué he de enterarme de las opiniones de los mortales, si yo ya tengo la Verdad?:

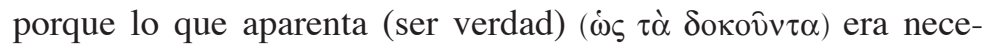

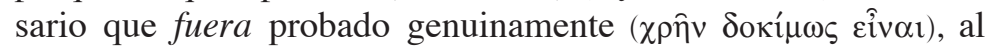
atravesar (con oído atento y reflexivo y visión crítica, es decir, con las yeguas conducidas por las Helíades) todo (el camino dis-

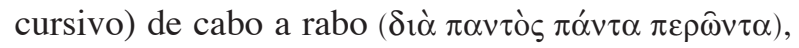

con lo que le daba a entender, como se ve, con sentido del humor, que lo que él tenía por Verdad podía muy bien no ser más que un cuerpo de opiniones mortales, y que por ello ya se había informado de uno de ellos sin darse cuenta; y con

\footnotetext{
alternadamente): puede entenderse en sentido óntico y en sentido verídico. En el primero, el pasaje expresa ("nutriéndolo"). Obsérvese que el sujeto para $\pi \varepsilon \rho \hat{\omega} v \tau \alpha$

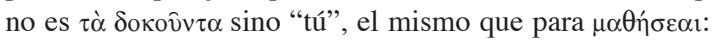

Sin embargo, estudiarás también éstas (= las opiniones), ya que las cosas que aparentan (ser)

era necesario que fueran genuinamente, al atravesar (con el intelecto) todas en toda su extensión.

Obsérvese la nueva frase elíptica; la hemos "nutrido" conectándola con B4 ("nutriéndolo" también):

Mira cómo las cosas ausentes (al ojo inquieto, B7. 4) están firmemente presentes al intelecto,

pues no separará, lo que está siendo, el estar unido a lo que está siendo,

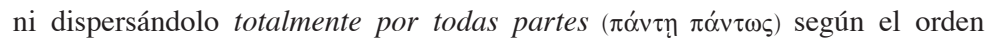

ni reuniéndolo (según el orden genérico).

(particular),

La conexión entre estos dos pasajes, con el cîvoı supuesto (B1. 31) y el explícito (B1. 32), ambos tomados en sentido óntico, está insinuada a propósito por Parménides mediante la singular contigüidad en cada uno, de dos palabras formalmente

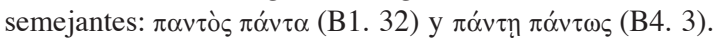

Por otra parte, el contenido de B4 supone ya conocido el de B8, por lo que el enlace entre ambos pasajes supone también una vuelta a la lectura de B1. 28-32. Y esto nos recuerda B5: “...me es igual por dónde comenzar (si por entender عîv $\alpha 1$ en sentido óntico o verídico), pues allí volveré una y otra vez”. En cuanto a este último sentido, es el que tomamos enseguida en nuestro texto.
} 
esto, la "Verdad" se habría desvanecido, lo que deja ver en este pasaje un sentido polémico que se agrega al didáctico con que había comenzado (B1. 28-30). ${ }^{37}$ La Verdad, para ser reconocida, debe ser confrontada con las "opiniones de los mortales". Éste es el sentido de enfrentarlas (B1. 29-30). Pero, al desvanecerse, como en el ejemplo presentado, la Verdad se nos revela no como algo ya dado, sino como algo por alcanzar, por investigar; la Verdad existe, pero como un ideal a ser alcanzado; de ahí que en B2 se aluda a ciertas "vías de investigación”, que también son enfrentadas y contrapuestas.

Por ahora disponemos de ciertas doctrinas, de ciertos "caminos" discursivos que han sido ya trazados por "caminantes" o "cocheros" que han seguido su propia vía de investigación. Sólo queda recorrerlos con nuestras "yeguas" y nuestras " $\mathrm{He}$ líades” para descubrir su entraña o "corazón” y ver lo que éste nos revela. Y así, nos refiere Parménides que su oído atento, conducido por su visión crítica, lo iba llevando de un camino discursivo a otro, abandonando una "morada nocturna" para ir a caer en otra "cada vez" (ö $\tau \varepsilon$, v. 8) en su búsqueda ardiente de la Verdad, como un nuevo Odiseo que va de un puerto a otro, sufriendo por llegar a su casa; hasta que de pronto, "naufragando", es decir, sintiéndose ya perdido, desorientado, se

\footnotetext{
${ }^{37}$ No queremos dejar de referirnos a otra más de las lecturas de B1. 31-32, la que se conecta precisamente con la última sección del poema: "a partir de aquí aprende opiniones mortales" (B8. 51-52); "te expreso el ordenamiento de todo lo verosímil (દ่oıкó $\alpha$ )" (B8. 60). Esto parece recordar la frase de Jenófanes (B35):

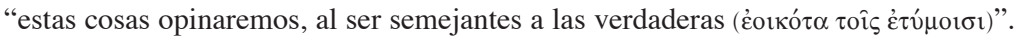
Ante esta formulación no podía faltar el sarcasmo de Parménides: ¿cómo se podría saber si un cuerpo de opiniones es semejante al de la Verdad? Para ello, habría que poner de un lado la doctrina de la Verdad bien redondeada (B1. 29) y del otro las de las opiniones de los mortales (B1. 30), y así "aprenderás también éstas, ya que lo que aparenta (ser semejante a la Verdad) era necesario que lo fuera realmente, al atravesar (nosotros) todas (las doctrinas) de cabo a rabo" (B1. 31-32) para comparar cada una con aquélla y poder, así, decidirse por alguna. Y esto, la ironía aparte, lo aprovecharía Parménides para expresar en la última sección del Poema la que sería la doctrina más semejante a la verdadera (¿la de Anaximandro?), para que a su vez el lector, juzgándola y atravesándola, pudiera dar el paso que supuestamente se requería para hacer de aquélla la doctrina de la Verdad.
} 
topa con unas "puertas" que le permiten, finalmente, el acceso a la deidad (= la Verdad) y a su camino.

Pero ¿qué significan estas "puertas de los caminos de la Noche y del Día”? ¿A qué caminos alude? Parménides ha recorrido muchos caminos nocturnos, pero intentando caminar por ellos "de día”, aplicando a ellos su visión crítica. Pero sus "Helíades" salen de cada uno teniendo que quitarse los "velos" de la cabeza en su intento de ver claro, de ir "hacia la luz" (v. 10). ¿Se refiere aquella alusión al último camino encontrado, que estaría representado por las puertas mismas?, es decir, ¿a un par de caminos, uno nocturno y el otro diurno? Cada camino de este par iestá representado por una de las hojas de la puerta? Cuando el "carro" de nuestro "cochero" recorría las "moradas de la noche", es decir, los caminos nocturnos, el eje del carro, "ardiendo" (¿refleja, este arder del eje, el ardiente deseo de luz de las Helíades?), lanzaba un silbido agudo y resonante al paso del "carro". Tal sonido (el símbolo de tal o cual contenido doctrinario), era como el canto de las Sirenas, que encanta al que lo escucha, pero no a Parménides-Odiseo. Cada uno de estos caminos nocturnos producía su propio en-

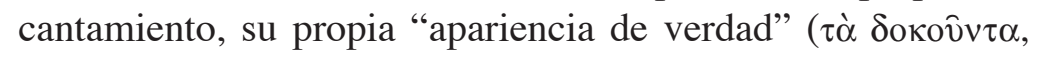
B1. 31). Y la visión crítica de nuestro filósofo no podía trazar con claridad su propio camino diurno cada vez (posiblemente porque su oído atento le transmitía voces que encerraban demasiado profundamente su "corazón", es decir, la entraña que pudiera revelar su falsedad), por lo que se "apresuraba" a salir de allí, "quitándose los velos de su cabeza". Pero al toparse el "carro" con unas "puertas", la apertura alternada de sus hojas produce un doble rechinido, tal vez uno agudo y el otro grave, representando aquél el contenido doctrinario del camino nocturno, y éste el del diurno. Al fin se produce, frente al nuevo camino de la noche, un camino del día bien definido y opuesto a aquél, tan opuesto que la separación de las dos "hojas" de la puerta, al abrirse, genera "un gran abismo" (B1. 18: $\chi \alpha ́ \sigma \mu$ '

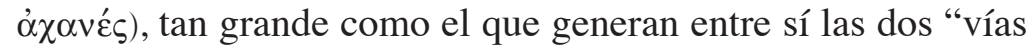


de investigación" de B2: la que (dice) "que es" (ö $\pi \omega \varsigma$ ह̌ $\sigma \tau \imath v)$ y

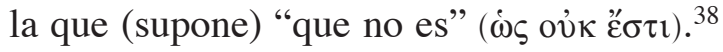

Esto nos sugiere que esta última vía nocturna presentaba un "corazón", una entraña, que se ofrecía más a la vista, por lo que la visión crítica del "cochero" ya podía hacer el trazo bien definido de su propia vía "del día", al desentrañar el "corazón perturbable" de la otra.

Pero ¿cuál es, en concreto, el último camino nocturno encontrado por el "carro", que es el representado por la hoja de la puerta que produce el rechinido agudo? Tal vez esto nos lo revele el paralelo que hemos visto un poco más arriba entre Parménides y Odiseo. ${ }^{39}$ Con esto, además, seguiremos considerando el significado de las adaptaciones y añadidos que aquella "segunda voz" de la que hablábamos había compuesto para dar un nuevo sentido a su relato.

Aquí debemos volver sobre el concepto de "puertas" aludido por el v. 13, es decir, el que nos revela la presencia de ecos reminiscentes distribuidos en el texto como "puertas" que hay que "atravesar" con nuestras "yeguas" y nuestras "Helíades". El v. 11 nos habla de las puertas "de los caminos de la noche y del día", y esto nos lleva por el Canto X de la Odisea, donde aparece esta expresión (v. 86), y donde nos enteramos de la llegada de Odiseo y sus hombres a la villa de los lestrigones, hombres gigantescos y caníbales, de la que acaban huyendo. Enseguida llegan a la isla de la Aurora, donde vive Circe, la divina hechicera. Una parte de sus hombres llega a la casa de Circe, a quien oyen cantar, y "el suelo resuena". Circe los invita a pasar y sólo uno, recelando un engaño, permanece afuera. A aquéllos, ya adentro, los convierte en cerdos.

\footnotetext{
${ }^{38}$ Obsérvese este nuevo paralelismo, entre B2 y la apertura de las puertas.

${ }^{39}$ Eric A. Havelock, "Parmenides and Odysseus", HSCP, 63, 1958, pp. 133143, habla de los ecos homéricos de Parménides, haciendo importantes y sugestivas observaciones, parangonando la heroicidad épica de Odiseo con la heroicidad literaria de Parménides, pero se le escapan los paralelos con el Canto VI de la obra homérica.
} 
Odiseo, informado, quiere rescatarlos, pero yendo en camino lo intercepta una aparición de Hermes, quien ("me tomó de la mano y me iba diciendo" Od., X, 280 ${ }^{40}$ le advierte de su imprudencia, al ir desarmado ante Circe, y le da una "hierba de vida" que extrae de la tierra y que lo hará invulnerable; "su raíz es muy negra, y su flor, del color de la leche". ¿Tiene algo que ver esto con Parménides? Este contexto del Canto X de la Odisea parece representar una transfiguración del contexto parmenídeo: hay también allí las puertas de la morada de una diosa; pero esta diosa es Circe, la hechicera, que engaña a todo el que entra desprevenidamente. También las puertas de Parménides (que pueden ser el Proemio mismo), pueden dar entrada a algún lector desprevenido, que no lleve en sus manos "la hierba de vida", y hacerlo caer en la trampa de Circe, quedando prisionero de ella y escuchando con "oído resonante" (B7. 4) y exterior ${ }^{41}$ el "canto de Circe", que hace

\footnotetext{
${ }^{40}$ Cf. vv. 22-23 de Parménides.

${ }^{41}$ Aquí es interesante observar que, mientras las yeguas representan el oído atento e interior, las ruedas (que generan en el eje un silbido resonante) y el carro pueden representar, respectivamente, los oídos externos resonantes y la cabeza. Esto recuerda un detalle, tal vez el único acertado, de la interpretación de Sexto Empírico. También sería interesante observar la relación que parece haber entre esta interpretación de las ruedas y el carro con B16, donde Parménides, al referirse al conocer humano común, lo conecta con la mezcla de ciertos órganos "muy errantes", supuestamente la del ojo inquieto con el oído "resonante" (B7. 4) (compárese esto con los mortales de "pensamiento errante" [B6. 6]). Pero el carro no representa siempre la cabeza física o la cabeza pensante del hombre común. Esto es así sólo en relación con las "ruedas" que lo mueven. Si lo consideramos en relación con las "yeguas" que lo conducen y con las "Helíades" que lo dirigen, se trata, como puede verse, del entendimiento o, en terminología parmenídea, del

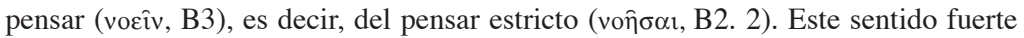

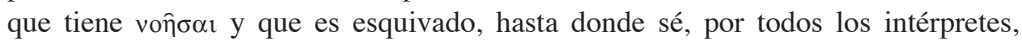
parece entrar en conflicto con la presentación de las dos vías de investigación que viene a continuación, ya que la segunda de ellas está lejos de ser o de llevar un pensar estricto. Esta es una nueva muestra de la actitud desafiante de Parménides, que a cada paso gusta de ponernos en dificultades, para incitarnos a resolverlas. La solución a ella, que se relaciona con la distinción parmenídea entre lo genérico y lo particular, que puede observarse en B4. 3-4 (ver nota 36, hacia el final), será tratada en otro lugar.
} 
resonar el suelo. ¿Qué significa esto? ¿A qué corresponde en el contexto de Parménides "la hierba de vida", que le permitirá a su lector transfigurar a Circe de vuelta en la diosa Verdad,

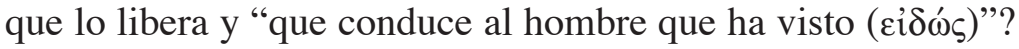
Veamos si en el texto de Parménides hay otras puertas que nos orienten.

En los vv. 25 y 27 del Proemio hay ecos del Canto VI de la Odisea, en el que se relata el recibimiento de Nausica a Odiseo, quien llega naufragado a su presencia. El v. 25 del Proemio: "tú que llegas a nuestra morada..." recuerda el v. 191 de dicho Canto:

mas ahora que a nuestra ciudad y comarca has llegado...

y el v. 27: “...que está alejado de los pasos de los hombres", los vv. 204-205 del mismo Canto:

Apartados vivimos en medio de un mar tempestuoso y tan lejos que ningún mortal con nosotros comercia.

Estos versos homéricos delimitan un "terreno" en el que se encuentra este curioso verso (v. 201):

No hay un hombre, ni nacerá alguno, que sea nuestro enemigo...

¿Es esta la "hierba de vida" que hay que extraer de dicho "terreno"? ¿Qué sentido puede tener esto? Lo que expresa este verso homérico es una singular profecía que se parece a otra que estaba en el aire, muy probablemente, en la época en que Parménides buscaba la Verdad, pues de ese modo sus contemporáneos habrían establecido fácilmente el vínculo insinuado así entre ellas:

...y en verdad ningún hombre vio y ninguno habrá que haya

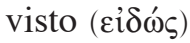

lo cierto acerca de lo divino y de las cosas de que hablo... 
Esto, que pertenece a un pasaje que conocemos como Jenófanes B34, y que era famoso en la Antigüedad, al decir de Guthrie, ${ }^{42}$ tiene ya un sentido como para introducirnos con él, al trasponer la primera parte del poema filosófico de Parménides. ¿Es esto lo que éste quiso insinuar mediante los ecospuerta que nos llevaron a ilustrar contextos parmenídeos con aquellos homéricos? Hay algo que parece confirmar la respuesta afirmativa. La "hierba" extraída tiene "la raíz negra y la flor blanca". El pasaje de Jenófanes tiene arriba, en el v. 1,

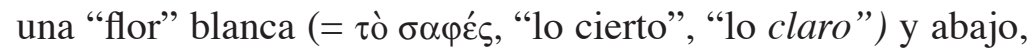

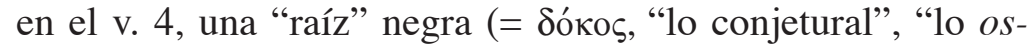
curo"). Este pasaje fue la "puerta" con que se topó finalmente Parménides para acceder a la diosa y su camino (= el camino del Día). Y esta "puerta" tiene, igualmente, arriba un dintel (= la flor blanca) y abajo un umbral de piedra (= la raíz negra), como nos señala el v. 12 de Parménides.

Una vez conocido por Parménides este pasaje, sus dos primeras líneas deben haberle llamado poderosamente la atención, pues ¿cómo puede alguien estar tan seguro de una profecía así? Además, si no hubo tal hombre ni lo habrá, será seguramente porque ya lo hay, habría pensado, siguiendo su acostumbrado sentido del humor. En su poema ocurre una expresión con esta misma estructura (B8. 5):

No era ni será todo junto, puesto que ahora lo es...

Parménides, pues, no comulgaba con aquel aserto ni con el pasaje completo de Jenófanes. Incluso lo contradice, cuando habla del camino de la deidad, "que conduce al hombre que sabe..."

Este pasaje de Jenófanes sería la última "morada de la noche" a la que entró el "carro" de Parménides, ya que, es-

\footnotetext{
${ }^{42}$ W. K. C. Guthrie, A History of Greek Philosophy, vol. I (The earlier Presocratics and the Pythagoreans), Cambridge, Cambridge University Press, 1962, p. 395.
} 
cuchando con atención más allá del silbido resonante del eje (= el conocimiento que confieren los oídos exteriores), el oído interior (= las yeguas) le mostró con claridad a la visión interna (= las Helíades) la entraña, "el corazón" perturbable de

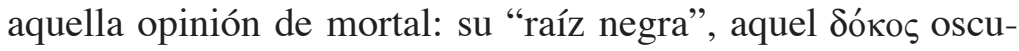
ro de Jenófanes (B34. 4) que origina una "planta" que "reniega" de su "flor blanca", marchitándola. Pero ésta sería una "hierba de muerte". ¿Dónde estaría la "hierba de vida"? Este "canto de la planta" es el rechinar de la primera hoja de la puerta que Díke, con una de sus llaves, hace girar. Es el caminar de la Noche, que muestra a flor de tierra la entraña de su ceguera, esto es, su "raíz negra". El rechinar de la otra hoja, que abre Díke con la otra llave, es el caminar del Día, que partiendo de la flor blanca como nueva raíz, va generando, por encima de la anterior, una nueva planta que es propiamente "la hierba de vida", que producirá nuevas flores; es también la "vía de la deidad (B1. 2-3), que lleva al hombre que sabe", es decir,

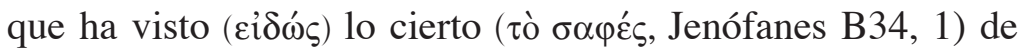

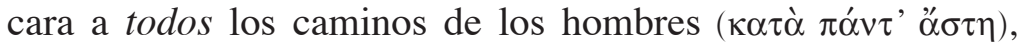
pues una vez descubierta la "raíz negra" en la última "morada de la noche", puede detectarse también en las demás.

Si esto es así, si Parménides alcanzó la Verdad, el camino del Día, mediante una consideración exhaustiva del pasaje mencionado de Jenófanes, de aquella vía nocturna cuyo "corazón perturbable" logró, al fin, desentrañar para trazar, por encima de él, su propio camino, después de sus fallidos intentos en el mismo sentido con otros textos filosóficos, significa que el método que siguió en la investigación de la Verdad fue la crítica y examen de opiniones y doctrinas ajenas, y que sólo pudo ordenar su pensamiento y alcanzar su propia doctrina cuando se topó con un pasaje ajeno de carácter predominantemente gnoseológico, que lo llevaría a consideraciones de este mismo carácter.

Pero, ¿nos revela Parménides algo de estas consideraciones? ¿Nos lo insinúa en algún lugar? Su discurso filosófico debe 
empezar por ellas, debe haber algo de esto en lo que conocemos como B2, B6 y B7. Y dichos pasajes deben estar abiertos a distintas lecturas, como hemos visto con B1. 31-32. Para entenderlos adecuadamente, hay que atender al último de sus desafíos, el mayor de todos, pues nos incita a que estudiemos ( $\mu \alpha \theta \dot{\eta} \sigma \varepsilon \alpha 1, B 1.31)$ el pasaje de Jenófanes de tal manera que,

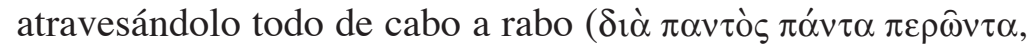
B1. 32) con oído y visión internos (= siendo llevados a través de él por nuestras yeguas y nuestras Helíades), logremos conformar nuestro propio "camino del Día" (que sería el mismo de Parménides), es decir, nuestro propio despliegue argumentativo de un discurso explícito y bien ordenado, del que pudiéramos, siguiendo la huella de Parménides, entresacar ciertos conceptos y ciertas frases para ordenarlos en un nuevo discurso: parco, ambiguo e insinuante, en algo así como los "fragmentos" B2, B6 y B7. 